\title{
レーザーコンプトン散乱ガンマ線ビーム技術開発と応用
}

\author{
宮本 修治 \\ 兵庫県立大学 高度産業科学技術研究所 ( ⿳ 千678-1205 兵庫県赤穂郡上郡町光都1-1-2)
}

\section{Development of Technology and Application of Laser Compton Scattering Gamma-Ray Beam}

\author{
Shuji MIYAMOTO \\ Laboratory of Advanced Science and Technology for Industry, University of Hyogo \\ 1-1-2 Kouto, Kamigouri, Ako-gun, Hyogo 678-1205
}

(Received August 21, 2013)

\begin{abstract}
A laser Compton gamma-ray beam is unique photon source that can supply polarized, tunable, quasimonochromatic high energy photon beam. This gamma-ray source has possibilities to apply to the maintenances, the conservation, the decommissioning and the security of atomic power plants. Present status of gamma-ray beamline on a synchrotron light facility NewSUBARU are reported. Quasimonochromatic gamma-ray beams from $1 \mathrm{MeV}$ to $73 \mathrm{MeV}$ photon energy are achieved. Photo-nuclear reactions using $17 \mathrm{MeV}$ photon energy were tested. Fast neutrons were measured by a time-of-flight technique. A dependence of neutron emission distribution on the polarization of gamma-ray was demonstrated. Nuclear transmutation for a disposal of radioactive nuclear waste and a generation of useful radioactive nuclei are tested.
\end{abstract}

Key Words: Compton scattering, Gamma-ray, Polarization, Photo-nuclear reaction, Neutron

1. はじめに

従来高エネルギーガンマ線の利用には, 放射性同位体 からの崩壊ガンマ線や, 電子加速器などを用いた制動輻 射ガンマ線が用いられてきた。レーザー・コンプトン散 乱 (Laser Compton Scattering: LCS) ガンマ線源は, これら 従来のガンマ線源に無い特徵を持ち, 準単色性, エネル ギー可変性, ビーム状放射に加えて, 優れた偏光特性に より, これを用いたガンマ線応用研究領域の拡大が期待 されている.このようなガンマ線ビーム源の新しい利用 施設が, 大型放射光施設SPring-8サイト内のニュースバ ル放射光施設に整備された，原子核との相互作用実験等 に有用な, $1 \mathrm{MeV}$ か $73 \mathrm{MeV}$ までのエネルギー領域で サブ $\mathrm{mW}$ クス $\left(10^{7} \gamma / \mathrm{s}\right)$ のガンマ線ビームが利用可能で ある ${ }^{1)}$. 更に高輝度・高フラックスのガンマ線ビームの 利用を目的として，エネルギー回収型リニアック (Energy Recovery Linac: ERL) を用いた試験システムの建設が, 日本原子力研究開発機構と高エネルギー加速器研究機構 の協力で進められている ${ }^{2,3)}$ 。この施設では, $10^{13} \mathrm{\gamma} / \mathrm{s} の フ$ ラックスのガンマ線発生と利用を目標としている。これ らの新しいガンマ線源は, 今後の原子力施設の保守保 全, あるいは廃止措置に有用なツールとなりうると考え られる。ここでは, LCSガンマ線ビーム源の特徴と現状 および応用研究の例を紹介する。
歴史的には，まずコンプトン散乱による高エネルギー 光子の発生が, 宇宙の星間光による高エネルギー電子の 減速機構の実証として理論的に検討された ${ }^{4}$. LCSガン マ線源の実験的研究はレーザー発明直後から, 世界各地 の電子蓄積リングを持つ加速器研究所で試験され た ${ }^{5,6)}$ 、レーザー装置の性能向上とともに，ガンマ線源 として他の光源には無い特徴が認識され, さらに放射光 施設などで電子蓄積リングの高性能化と利用施設の充実 により，高エネルギー光子の発生と利用が積極的に図ら れるようになった. 大型放光施設 SPring-8の電子蓄積り ング(電子エネルギー $8 \mathrm{GeV}$ ) では, レーザー電子光 (LEP) と呼ばれるLCSガンマ線ビームライン (BL33LEP) が建設され，紫外レーザーを用いて，エネルギーを高精 度で同定した $2 \mathrm{GeV}$ を超える偏極光子を発生して，ハド ロン核物理研究に利用している77. さらにSPring-8では 遠赤外レーザー光 (波長約 $100 \mu \mathrm{m}$ ) を用いて, ガンマ線 発生による電子損失が生じない, $10 \mathrm{MeV}$ 付近のガンマ 線を発生する試験も行われた ${ }^{8}$.

定常的にMeVエネルギーのガンマ線を発生できる光 源は世界的にみても少なく, 本稿で紹介するニュースバ

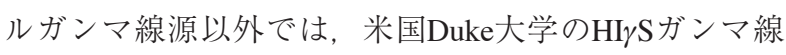
源と, 産業技術総合研究所の電子蓄積リングTERASガ ンマ線源のみであった。 TERASは1980年代後半から外 部レーザーを用いたレーザーコンプトン散乱ガンマ線源 
の研究を進め, 核物理研究やガンマ線非破壊検査などガ ンマ線応用研究を積極的に推進して成果を上げてきた が9-11), 装置の老朽化に加え, 東日本大震災の被災によ り閉鎖となった。 Duke大学の, HIGS施設 ${ }^{22}$ は, 電子エ ネルギー0.2-1.2 GeVの蓄積リングにより発生した自由 電子レーザーの波長可変性と, レーザー共振器内の高い 光子密度を利用して, ガンマ線エネルギー可変 (1$100 \mathrm{MeV})$ で, 高フラックス $\left(10^{6}-10^{7} \gamma / \mathrm{s}\right)$ ガンマ線源を実 現している.

なお，一般には「ガンマ線」は，電磁相互作用により原 子核から放出される電磁波をさすが, ここでは, 高エネ ルギー電磁波, 特にエネルギーが100 keV程度以上の光 子の意味で用いている。

\section{2. レーザーコンプトン散乱ガンマ線}

\section{1 発生原理と特徵}

コンプトン散乱光源の特徵を明確にするために，電子 エネルギーとレーザ光子エネルギー, および散乱動力学 から決まるガンマ線スペクトルの角度分布をもとに, 加 速器パラメータの違いによる, 光源特性の比較を行う。

Fig. 1のように，高エネルギー電子ビームに対して， 正面からレーザ光ビームを入射して，レーザ光子が電子 進行方向にコンプトン散乱する配置を考える。この場 合, 散乱光子エネルギーと散乱角度の関係は, 次式で表 される。

$$
E_{\gamma}(\theta)=\frac{4 E_{L} \gamma^{2}}{1+\gamma^{2} \theta^{2}+4 \gamma E_{L} / m c^{2}}
$$

ここで, $\gamma=E_{e} / m c^{2}$ はローレンツ係数, $E_{e}$ は電子エネル ギー, $m c^{2}$ は電子の静止エネルギー， $E_{L}$ はレーザ光子エ ネルギー, $\theta$ は電子ビーム進行方向に対する散乱光子の 出射角度, $4 E_{L} \gamma / m c^{2}$ は散乱光子の電子に対する反跳効果 である。Fig. 2にこの関係を図示する。散乱角度で, $1 / \gamma$ 程度の範囲に高いエネルギーの散乱光子が集中すること がわかる. 数值例としては, エネルギー $1 \mathrm{GeV}$ 電子 ビームに対して, $\mathrm{Nd}: \mathrm{YVO}_{4} レ$ レ゙(波長 $1064 \mathrm{~nm}$ )を入射 した場合, 軸上 (散乱角度 $\theta=0)$ には, $E_{\gamma}=17.5 \mathrm{MeV}$ の ガンマ線が散乱する。エネルギー分布の角度広がりは, $\theta_{1 / 2}=1 / \gamma=0.5 \mathrm{mrad}$ とる. 一方, ガンマ線フラックス の幅も $1 / \gamma$ となり, 半数の散乱光子が, 半值半角 $0.5 \mathrm{mrad}$ に含まれることになる。この放射分布は，散乱粒子であ る電子の座標系から, 実験室系へのローレンツ変換で決 まるため，シンクロトロン放射光が電子軌道前方に集中 して高輝度な放射となる原理と同様に, ビーム状のガン マ線源となることを示す。散乱中心軸にガンマ線コリ メーターを設置することで，エネルギー広がりが小さい

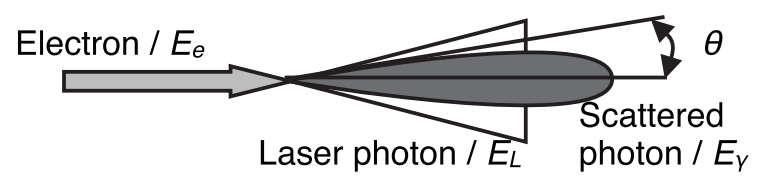

Fig. 1 Schematic of laser Compton scattering gamma-ray generation at head-on collision.

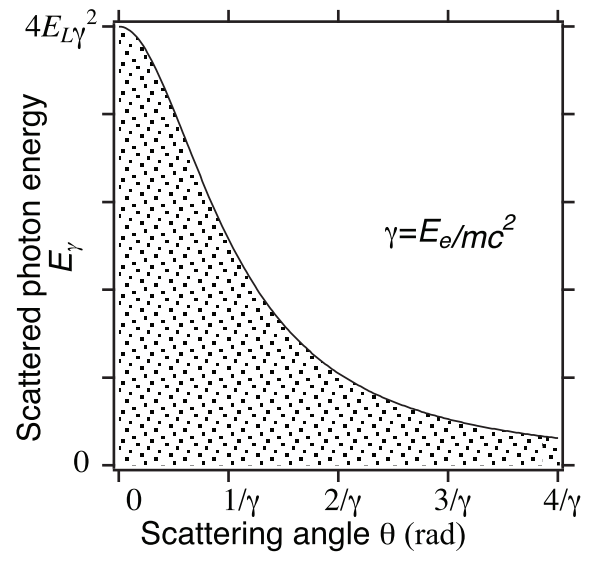

Fig. 2 Dependence of gamma-ray photon energy on the scattering angle $\theta$.

(a)
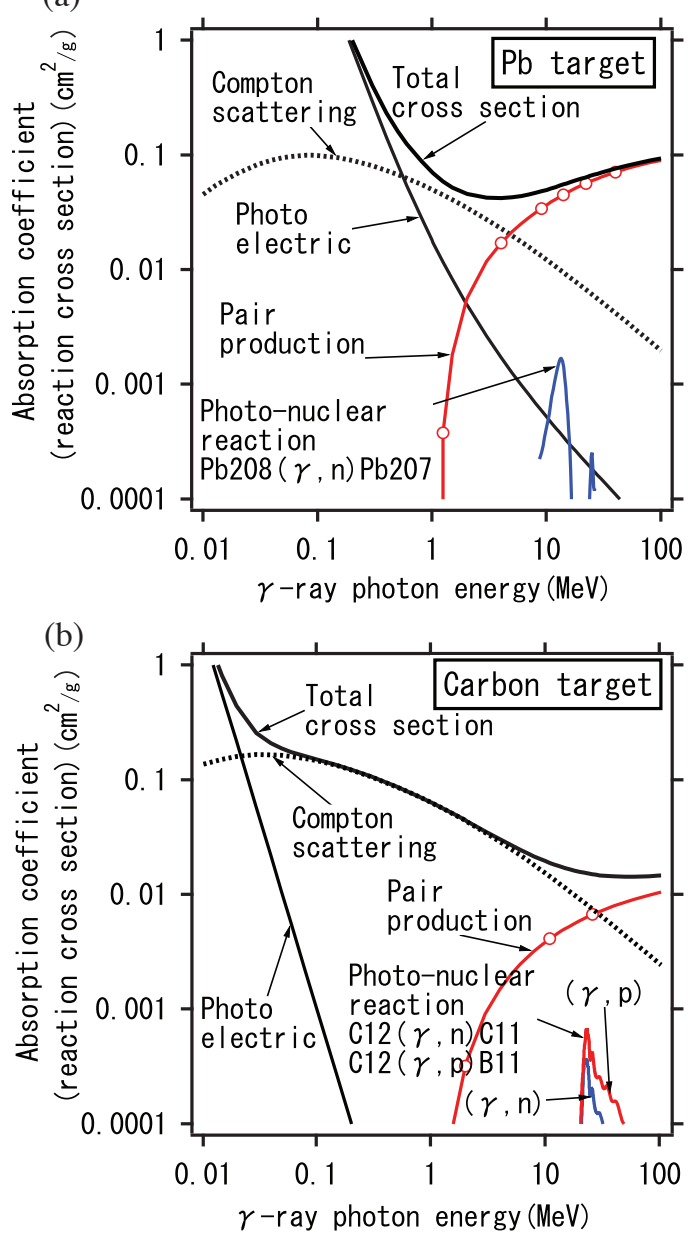

Fig. 3 Absorption cross section of photon in (a) $\mathrm{Pb}$ and in (b) carbon target. Data used are from NISTXCOM photon cross sections database and RISTJENDL nuclear database.

準単色ガンマ線源として利用できる，数值例では，散乱 点から $20 \mathrm{~m}$ の位置に直径 $3 \mathrm{~mm}$ のコリメーター設置する と, 散乱光子ビームを $0.15 \mathrm{mrad}$ の角度で切り出すこと に対応し，理想的にはエネルギー広がり $3 \%$ のガンマ線 ビームが得られる。

また, 上記パラメー夕領域では, 散乱の全断面積は, ほぼThomson散乱の断面積となり, 


$$
\sigma_{T}=\frac{8 \pi}{3} r_{0}^{2} \approx 0.665-\text { barn }
$$

程度である。ここで, $r_{0}=e^{2} / m c^{2}$ は電子の古典半径. コ ンプトン散乱断面積の量子力学的取り扱いは, Klein-仁 科の式で計算される.

散乱ガンマ線の偏光特性は, 入射レーザー光子の偏光 を保存するが, 電子から見てレーザー入射方向以外へ散 乱された光子は，ローレンッ変換により偏光を回転させ ながら電子進行方向に集中するため, ガンマ線ビームの 軸の周囲は異なる偏光を含む。 ガンマ線ビームを, 電子 ビーム軸を中心とした $1 / \gamma よ り 十$ 分小さい開口角度のコ リメーターで切り出すことにより, $90 \%$ 以上の高い偏光 度のガンマ線ビームを利用することが出来る。入射レー ザーの偏光を切り替えることで, 直線偏光あるいは右回 り・左回り円偏光ガンマ線を高速に切り替えることが可 能で，他のガンマ線源にはないユニークな特徵である. 磁気コンプトン散乱等, 電子のスピンに依存した散乱計 測の応用に用いられている13).

\section{2 ニュースバル・ガンマ線ビームライン}

Fig. 4にガンマ線ビームラインの概略を示す。ニュー スバル放射光施設 ${ }^{14)}$ は, 電子エネルギー0.5 GeVから $1.5 \mathrm{GeV}$ 可変の軟X線放射光施設で, 現在9本の放射光 ビームラインが利用されている。 BL01がLCSガンマ線 ビームラインである。このビームラインは直線部下流に あり, 電子とレーザー光子の衝突点は, 直線部中央部 (衝突点1：短波長レーザー用) と, 下流の偏光電磁石直 前の部分(衝突点2：長波長レーザー用)を設定してい る。この2箇所で, 電子ビームは $0.5 \mathrm{~mm}$ 程度に収束して いる。レーザー装置は加速器収納トンネル外に設置し, ミラー, レンズ, 空を介して, 真空ダクト内に導き, 真 空槽内の最終ミラーで折り曲げて, 衝突点へ導いてい る. 発生するガンマ線は, 最終ミラーおよび真空空を透 過して大気中に取り出し, そのままガンマ線ハッチ1お よび2へ導入される. ガンマ線コリメーターは, 加速器 収納トンネル内およびガンマ線ハッチ1に設置した自動 ステージに載せた，厚さ $100 \mathrm{~mm}$ 鉛にコリメータ孔を 開けたものを用いている. Table 1に代表的な3つの波長 のレーザーを用いた場合の, ガンマ線エネルギーおよび
Table 1 Energy and normalized yield of gamma-ray beam at BL01. Usable flux of gamma-ray is 3000 times of the normalized yield, when electron current of $300 \mathrm{~mA}$ and $10 \mathrm{~W}$ laser was used.

\begin{tabular}{lcccc}
\hline Lasers & $\mathrm{Nd}(\omega)$ & $\mathrm{Nd}(2 \omega)$ & $\mathrm{CO}_{2}$ \\
\hline Laser wavelength $(\mathrm{nm})$ & 1064 & 532 & 10590 \\
\hline Electron energy (collimator) & \multicolumn{2}{c}{ Collimated $\gamma$-ray energy $(\mathrm{MeV})$} \\
\cline { 2 - 4 }$E_{e}=974 \mathrm{MeV} \quad(25 \mathrm{~mm} \phi)$ & $6.0-16.7$ & $12-33$ & $0.6-1.7$ \\
& $(3 \mathrm{~mm} \phi)$ & $15.8-16.7$ & $31-33$ & $1.6-1.7$ \\
$E_{e}=1470 \mathrm{MeV}(25 \mathrm{~mm} \phi)$ & $7.6-37.6$ & $15-73$ & $0.7-3.9$ \\
\hline Electron energy $($ collimator $)$ & \multicolumn{2}{c}{ Normalized $\gamma$-ray yield $(\gamma / \mathrm{s} / \mathrm{mA} / \mathrm{W})$} \\
\cline { 2 - 4 }$E_{e}=974 \mathrm{MeV} \quad(25 \mathrm{~mm} \phi)$ & 6000 & 3000 & 7200 \\
\cline { 2 - 4 } & $(3 \mathrm{~mm} \phi)$ & 260 & 130 & 480 \\
\hline
\end{tabular}

計測したガンマ線規格化フラックスを示す ${ }^{15-18)}$.

Fig. 5には, 高分解のGe検出器で測定した, 準単色ガ ンマ線スペクトルの例を示す。この計測では, 制御シス テムでの電子エネルギーを $800 \mathrm{MeV}, \mathrm{CO}_{2}$ レーザーを用 い, 直径 $1 \mathrm{~mm}$ のコリメーターをハッチ1に設置して測定 した。計測されたガンマ線の最大エネルギー(1.177 $\mathrm{MeV})$ から電子ビームのエネルギーは約 $810 \mathrm{MeV}$ と計算 され，蓄積リング内の電子エネルギーを計測することが 出来た。計測精度は， $0.07 \%$ 程度と評価されている。

\section{LCSガンマ線ビームの応用研究}

LCSガンマ線ビームの応用研究は, 核物理 ${ }^{19)}$, 宇宙核 物理 ${ }^{20)}$, 陽電子生成 ${ }^{21)}$ との利用, 遮蔽体試験, 同位体 の非破壊検出 ${ }^{22)}$, 特に核燃料物質の高精度検出 ${ }^{23)}$, 磁気 コンプトン散乱計測 ${ }^{13)}$ などが実施されている。ここで は, 光核反応のガンマ線偏光依存計測と, 核変換試験に 関して紹介する。

高速中性子の計測には，プラスチックシンチレーター を用いて, 飛行時間法で散乱ガンマ線と分離して計測し た ${ }^{16)}$ ．電子蓄積リングを単バンチ運転することにより, 電子周回時間386 ns毎に，ガンマ線パルスを発生し， ターゲットに照射する。 ターゲットからは，光核反応中 性子と散乱ガンマ線が発生するが, 飛行時間差により分 離して，中性子のフラックスとエネルギーが測定でき

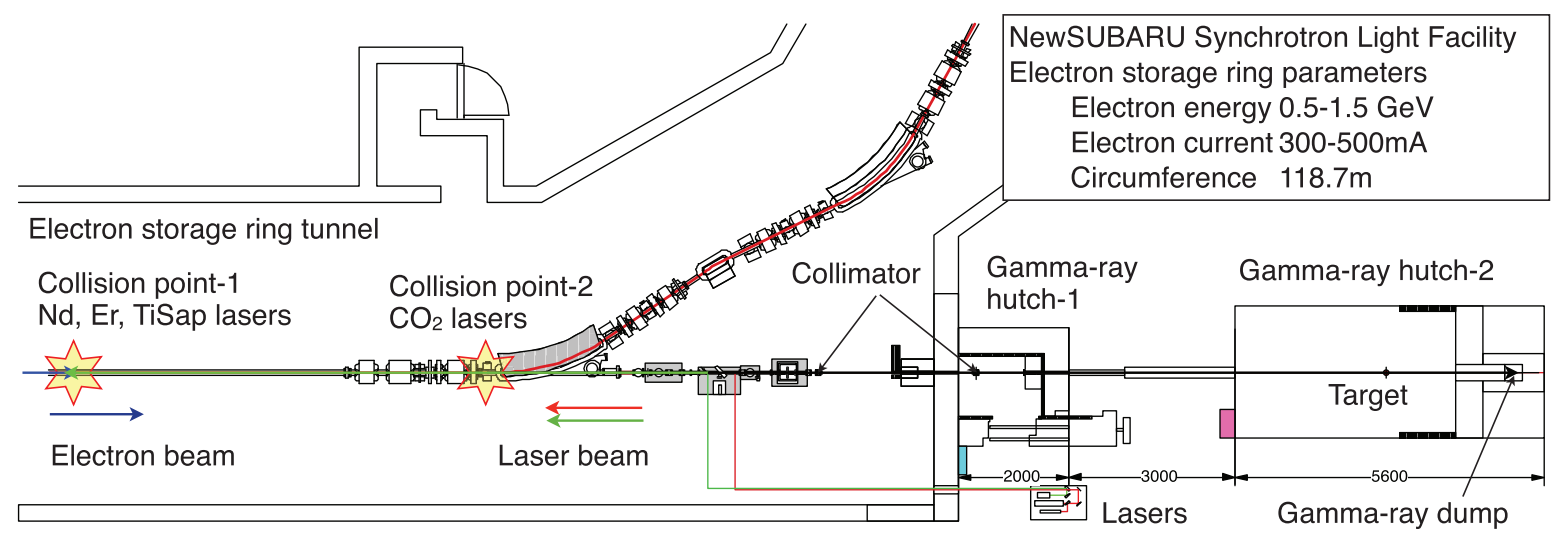

Fig. 4 Layout of laser Compton scattering gamma-ray beam source on NewSUBARU BL01. Two collision points and two gamma-ray irradiation hutches are shown. Two collimators located in the accelerator tunnel and in the hutch- 1 . 


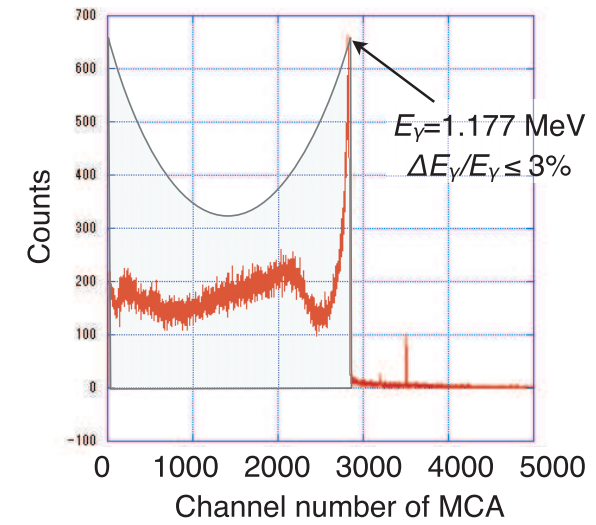

Fig. 5 Example of LCS gamma-ray spectrum. Data was taken by pure-Ge detector at electron energy of $800 \mathrm{MeV}$, with $\mathrm{CO}_{2}$ laser and $1 \mathrm{~mm} \Phi$ collimator. Calculated full-spectrum is shown as gray line.

る。この計測法を用いて, ガンマ線ビーム軸に対して, 垂直方向に放出される $(\gamma, \mathrm{n})$ 光核反応中性子のガンマ線 偏光依存性を測定した. Fig. 6 (a) に, 偏光方向 $\left(\Phi=0^{\circ}\right)$ および偏光に垂直方向 $\left(\Phi=90^{\circ}\right)$ で計測された197-Au ターゲットからの中性子スペクトル例を示す. 光核反応 の中性子放出分布がガンマ線偏光に依存することは, 50 年以上前に, A. Agodi ${ }^{24)}$ が理論計算しており, ガンマ線 偏光方向に対する角度 $\Phi$ について, $\mathrm{Y}(\Phi)=a+b \cdot \sin ^{2} \Phi$ の発生分布をすると予測をされているが，明確な実験的 計測の報告がなかった。この分布を $\mathrm{Au}$ ターゲットにつ いて計測した結果をFig. 6 (b)に示す。実線は, 偏光角 度に対する分布を $\mathrm{Y}(\Phi)$ にフィッティングした関数であ る。この観測結果は, 偏光に垂直方向に約2倍の中性子 発生がある分布を示しており, 電気双極子共鳴で偏光方 向に引き伸ばされる様に変形した原子核からの中性子放 出を示唆している. Fig. 6 (c) に質量数の異なる原子核 からの中性子発生分布の偏光依存の異方性 $(b / a)$ を質量 数に対してプロットしたものを示す。原子核の共鳴状態 (変形状態)に依存して, 中性子発生分布は変わると考え られるため, LCS偏極ガンマ線を用いるこの計測手法は 原子核の構造を調べる手法として応用可能と思われる。

上述の光核反応による中性子放出は, ガンマ線による 核変換と考えることも出来る. 娘核が短寿命放射性同位 体であれば，壊変により別の元素に変換できる．Fig. 7 に，ニュースバル・ガンマ線源で試験した，2種の核変 換のポンチ絵を示す．Fig. 7 (a)の129-Iは，運転中の原 子炬で年間 $5 \mathrm{~kg}$ 程度生成される, 長寿命放射性核種で, 寿命が 1570 万年あり，放射能は比較的弱いが，長期の管 理が困難である。これをガンマ線照射で，安定核種に変 換することが出来る。129-I $(\gamma, \mathrm{n})$ 128-Iの光核反応断面積 をニュースバルLCSガンマ線源で測定した ${ }^{25)}$. LCSガン マ線の特徵である，準単色でビーム状の特性を活かし て，1 mg程度のサンプルで，断面積の測定は可能であ る。測定結果は, 別の手法で測定されていた結果とほぼ 同じであり，ガンマ線による変換効率は3\%程度であっ た，放射性廃棄物の処理としての実用には，光核反応中 性子の利用など，効率を改善する手法が必要である. (a)

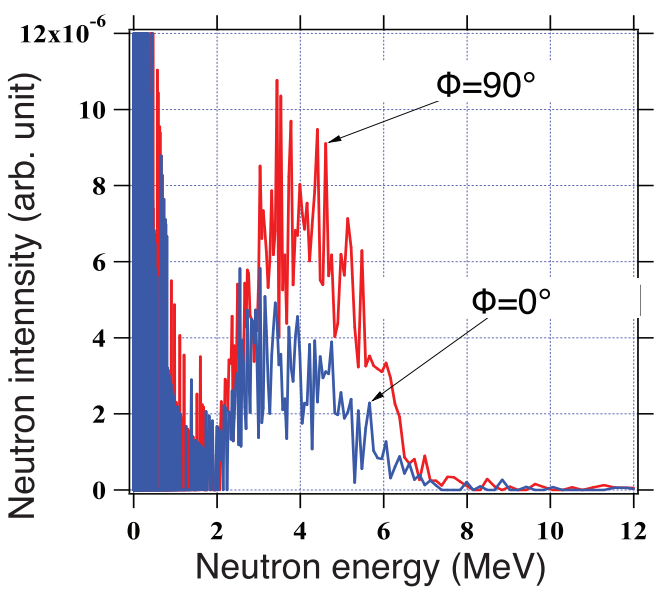

(b)

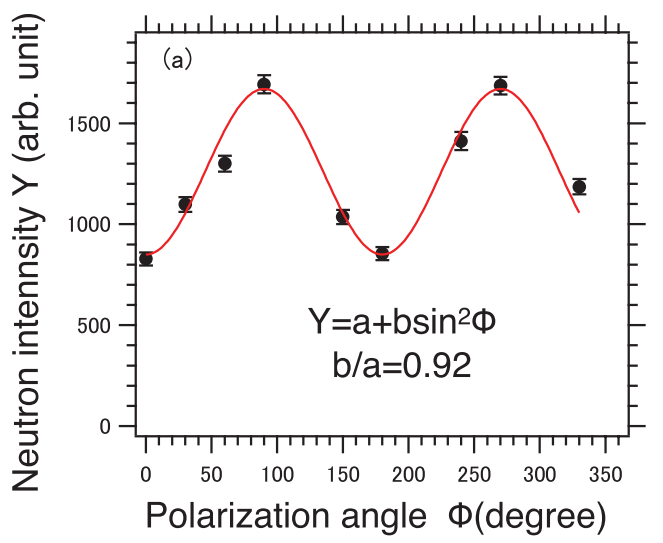

(c)

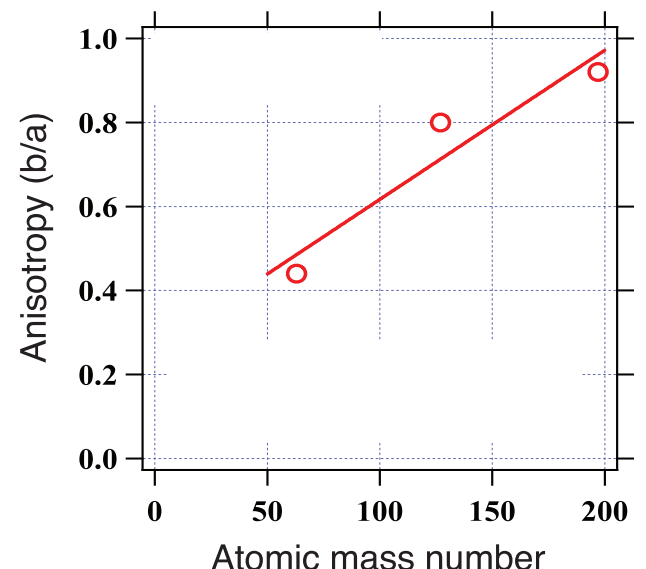

Fig. 6 (a) Measured neutron spectrum of 197-Au $(\gamma, n)$ 196-Au reaction. Two spectrum shows parallel $\left(\Phi=0^{\circ}\right)$ and perpendicular $\left(\Phi=90^{\circ}\right)$ to the polarization of gamma-ray. (b) Angular distributions of neutrons. The solid line shows a function in form of $a+b \cdot \sin ^{2} \Phi$. (c) Dependence of anisotropy on the atomic mass number of three different target, gold, iodine and copper.

Fig. 7 (b) は, 核医学検査に最も多く使われている, 99-Tc ${ }^{\mathrm{m}}$ の製造を，ガンマ線照射で行うための核反応を示 している，共鳴光核反応による同位体核変換手法であ る。核医学検査 (Single Photo Emission Computed Tomography: SPECT) では, 99- $\mathrm{Tc}^{\mathrm{m}}$ 薬剤を静注し, 半減期6時間 ほどで放出される143 keVのガンマ線をCT検出に用い る。ガンマ線を100-Moに照射して，光核反応で99-Moを 製造する。100-Moは，自然のMoにも9.6\%程度含まれて 
(a)

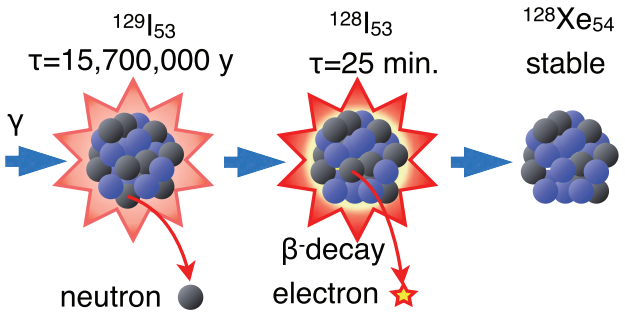

(b) ${ }^{100 \mathrm{Mo}_{42}}$

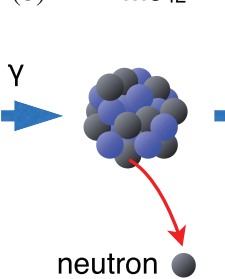

neutron

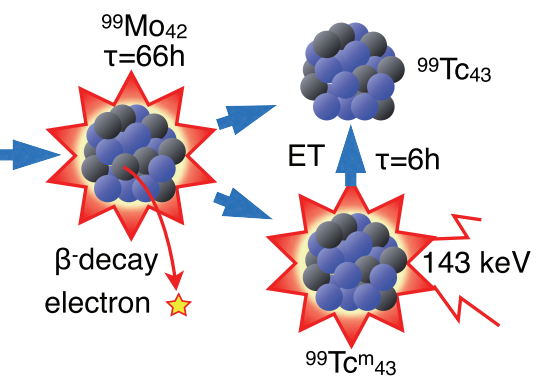

Fig. 7 Tested examples of transmutation. (a) Radioactive waist 129-I was irradiated by $16.7 \mathrm{MeV}$ gammaray beam. Generated 128 -I change rapidly to the stable $128-X e$. (b) Medical radioactive nuclei 99-Tcm was generated by irradiating enriched Mo.

いる。実験では100-Mo試料を用い，12-16.7 MeVガンマ 線を照射した ${ }^{26)}$ ，同時に光核反応断面積がよく調べられ ている197-Auを照射しリファレンスとした。計測で 得られた $100 \mathrm{Mo}(\gamma, \mathrm{n}) 99 \mathrm{Mo}$ 反応の断面積は0.109 barnであ り，他の計測と一致していた。この值は，ニュースバル で1週間程度ガンマ線照射すれば，小動物用核医学検査 の99- $\mathrm{Tc}^{\mathrm{m}}$ が製造できる程度の值である。短半減期同位体 であり，保存がきかないため，実際の応用では高いガン マ線フラックスが必要となる。ニュースバル・ガンマ線 の100万倍高いガンマ線フラックスを想定する次世代 ERLガンマ線源の稼働により，ガンマ線核変換による有 用同位体製造は現実のものとなると考えられる。

\section{4. まとめ}

ニュースバル放射光施設のレーザー・コンプトン散乱 ガンマ線ビーム源に照射ハッチを追加して，1-73 MeV のガンマ線ビームを $0.33 \mathrm{~mW}$ 強度で利用できるように なった。このガンマ線源を用いて, 核物理, 宇宙核物 理, 陽電子生成, 遮蔽体試験, 非破壊検査, 磁気コンプ トン散乱計測などが実施されている。 これに加えて, 光 核反応を利用した核変換試験，遮蔽体検査などへの応用 も実施している

\section{謝 辞}

ニュースバル放射光施設ガンマ線源の開発に協力いた だいた, 兵庫県立大学高度産業科学技術研究所の研究 者, 学生およびSPring-8 - 高輝度光科学研究センター, 理化学研究所の研究者に謝意を表します。また，ガンマ 線ビームラインの設置と利用研究に協力いただいた, レーザー技術総合研究所・今崎一夫博士，李 大治博士，
井澤 靖和所長, 甲南大学・宇都宮 弘章先生, 山県民穂 先生，日本原子力研究開発機構・早川岳人博士，静間 俊行博士, 大阪大学核物理研究センター・嶋 達志先生, 江尻 宏泰先生に謝意を表します。

\section{参考文献}

1) Y. Asano, S. Miyamoto, and LEPS-II collaboration: Proc. 12th Int. Conf. Radiation Shielding, Nara, 2012 (Atomic Eneegy Sciety of Japan, Tokyo, 2013) to be published.

2) R. Hajima: ICFA Panel on Advanced and Novel Accelerators Newsletter, Dec. (2009) 29.

3）羽島良一：エネルギー回収型リニアックによる次世代レー ザーコンプトン散乱 $\gamma$ 線源(次世代レーザーコンプトン散乱 ガンマ線源とその利用, 大垣 英明, 早川岳人編, 京都大 学, 京都, 2013) ISSN 1342-3185, p.142.

4) E. Feenberg and H. Primakoff: Phys. Rev. 73 (1948) 449.

5) R. H. Milbum: Phys. Rev. Lett. 10 (1963) 75.

6) C. Bempora, R. H. Milburn, and N. Tanaka: Phys. Rev. 138 B (1965) 1546.

7) T. Nakano, D. S. Ahn, J. K. Ahn, H. Akimune, Y. Asano, W. C. Chang, S. Daté, H. Ejiri, H. Fujiwara, M. Fujiwara, et al.: Phys. Rev. Lett. 91 (2003) 012002.

8) K. Kawase, Y. Arimoto, M. Fujiwara, S. Okajima, M. Shoji, S Suzuki, K. Tamura, T. Yorita, and H. Ohkuma: Nucl. Instrum. Meth. A 592 (2008) 154.

9) H. Ohgaki, S. Sugiyama, T. Yamazaki, T. Mikado, M. Chiwaki, K Yamada, R. Suzuki, T. Noguchi, and T. Tomimasu: IEEE Trans. Nucl. Sci. 38 (1991) 386.

10) H. Toyokawa, H. Ohgaki, and T. Shima: IEEE Trans. Nucl. Sci. 49 (2002) 182

11) 宇都宮弘章：日本物理学会誌 62 (2007) 34

12) V. N. Litvinenko, B. Burnham, M. Emamian, N. Hower, J. M. J. Madey, P. Morcombe, P. G. O'Shea, S. H. Park, R. Sachtschale, K. D. Straub, et al.: Phys. Rev. Lett. 78 (1997) 4569.

13) 坂井信彦, 早川岳人, 宮本修治：磁気コンプトン散乱に よる磁性材料の研究(次世代レーザーコンプトン散乱ガン マ線源とその利用, 大垣英明, 早川岳人編, 京都大学, 京都, 2013) ISSN 1342-3185, p.37.

14) A. Ando, S. Amano, S. Hashimoto, H. Kinosita, S. Miyamoto, T. Mochizuki, M. Niibe, Y. Shoji, M. Terasawa, T. Watanabe, et al.: J. Synchrotron Radiation 5 (1998) 342.

15) S. Miyamoto, Y. Asano, S. Amano, D. Li, K. Imasaki, H. Kinugasa, Y. Shoji, T. Takagi, and T. Mochizuki: Radiation Measurements 41 (2007) S179.

16）宮本修治，堀川賢：レーザー研究 36 (2008) 798

17) S. Amano, K. Horikawa, K. Ishihara, S. Miyamoto, T. Hayakawa, T. Shizuma, and T. Mochizuki: Nucl. Instrum. Meth. Phy. Res. A 602 (2009) 337.

18) K. Horikawa, S. Miyamoto, S. Amano, and T. Mochizuki: Nucl. Instrum. Meth. Phys. Res. A 618 (2010) 209.

19) T. Hayakawa, T. Shizuma, S. Miyamoto, S. Amano, K. Horikawa, K. Ishihara, M. Mori, K. Kawase, M. Kando, N. Kikuzawa, et al.: Phys. Rev. C 77 (2008) 068801.

20) T. Shima, Y. Nagai, S. Miyamoto, S. Amano, K. Horikawa, T. Mochizuki, H. Utsunomiya, and H. Akimune: AIP Conf. Proc. 1235 (2010) 315.

21) D. Li, K. Imasaki, S. Miyamoto, K. Horikawa, S. Amano, and T. Mochizuki: Appl. Phys. Lett. 94 (2009) 091112.

22) T. Shizuma, T. Hayamawa, R. Hajima, N. Kikuzawa, H. Ohgaki, and H. Toyokawa: Rev. Sci. Istrum. 83 (2012) 015103.

23) H. Toyokawa, H. Ohgaki, T. Hayakawa, T. Kii, T. Shizuma, R. Hajima, N. Kikuzawa, K. Masuda, F. Kitatani, and H. Harada: Jpn. J. Appl. Phys. 50 (2011) 100209.

24) A. Agodi: Il Nuovo Cimento 1 (1957) 21.

25) K. Horikaw, T. Mochizuki, S. Miyamoto, S. Amano, T. Watanabe, D. Li, K. Imasaki, and Y. Izawa: Rev. Laser Eng. 39 (2011) 445.

26) H. Ejiri, T. Shima, S. Miyamoto, K. Horikawa, Y. Kitagawa, Y. Asano, S. Date', and Y. Ohashi: J. Phys. Soc. Japan 80 (2011) 094202-1. 